\title{
Effect of the composting process on physicochemical properties and concentration of heavy metals in market waste with additive materials in the Ga West Municipality, Ghana
}

\author{
Carl Tibu $^{1} \cdot$ Ted Y. Annang $^{1} \cdot$ Negasi Solomon $^{1,2} \mathbb{D} \cdot$ Dzidzo Yirenya-Tawiah $^{1}$
}

Received: 20 February 2018 / Accepted: 15 April 2019 / Published online: 16 May 2019

(c) The Author(s) 2019

\begin{abstract}
Purpose The main objective of this study was to assess the physiochemical properties and phytotoxicity of compost made from different organic waste materials sourced from local markets.

Methods The Stack pile composting was carried out with market waste, sawdust, rice straw, and swine manure in four different combinations. Parameters such as temperature, $\mathrm{pH}$, nitrogen, phosphorus, potassium, and heavy metal concentrations were monitored. Germination test with water extracts of the composts was done to assess phytotoxicity of the composts.

Results All compost piles recorded temperatures of $38^{\circ} \mathrm{C}$ slightly above the recorded ambient temperature of $34{ }^{\circ} \mathrm{C}$ at the start of composting. The $\mathrm{pH}$ value ranged from 7.12 to 8.2 for the different compost types. The total organic carbon and total nitrogen values ranged from $27.05-31.06$ to $0.77-0.97 \%$, respectively. The total phosphorus and total potassium values ranged from 0.2-1.87 to 0.39-2.3\%, respectively, for different compost types. The $\mathrm{C} / \mathrm{N}$ ratio values ranged from 29.09:1 to 36.22:1. All the composts had heavy metal concentrations below the Canadian Council of Ministers of the Environment standards. Germination indices, a measure of plant vs supporting potential, ranged from 80 to $99 \%$ for Solanum lycopersicum, 170 to 198\% for Cucumis sativus, and 114 to 166\% for Brassica oleracea.

Conclusion The study confirms the notion that composting municipal solid waste is a viable organic waste management strategy, and with the potential to enhance waste management system, while promoting cultivation of vegetables for food security.
\end{abstract}

Keywords Physical properties $\cdot$ Chemical properties $\cdot$ Compost $\cdot$ Germination test

\section{Introduction}

Municipal solid waste (MSW) comprises waste from household, offices, markets, construction and demolition debris, dead animals and abandoned vehicles and public places (Cointreau 1982; Niazi et al. 2016), and its management is presently an issue of global concern (Thomas-Hope 1998). Very high volumes of municipal solid waste are being

Ted Y. Annang

tyannang@ug.edu.gh

Negasi Solomon

solomonnegasi@gmail.com

1 Institute for Environment and Sanitation Studies, University of Ghana, P. O. Box 209, Legon, Ghana

2 Department of Land Resources Management and Environmental Protection, Mekelle University, P. O. Box 231, 7000 Mekelle, Ethiopia generated particularly in urban areas, and are increasing rapidly as a result of population growth and changing consumption pattern resulting from changing economic situations. The challenges of municipal solid waste management are particularly grave in developing and low-income countries, where waste management is primarily the responsibility of local authorities (Guerrero et al. 2013; Henry et al. 2006). On average up to $50 \%$ of residents lack collection services in urban areas of low- and middle-income countries (Kathirvale et al. 2004).

The sheer volume of MSW generated in Ghana's urban centres is devastating. Accra, for instance, had an estimated population of about 2.7 million inhabitants and generated about 1000 tons of solid waste daily in the year 2000 (Miezah et al. 2015). Between 2000 and 2010, the city's population had doubled to about 4 million inhabitants and generated about 2500 tons of waste per day (Oteng-Ababio et al. 2013). The World Bank projects a municipal solid waste generation of 9800 tons per day in Accra by 2025 as 
the city expands with more urbanized suburbs. In Ghana, the rate of waste generation is $0.47 \mathrm{~kg} /$ person/day (Miezah et al. 2015), which translates into about 12,710 tons of waste per day per the current population of 27,043,093 (Douti et al. 2017). Ghana like other developing countries has over the years had difficulties in municipal solid waste management. Solid waste management in Ghana, as in other places in the developing world, has generally involved collection and disposal at unauthorized dumpsites or landfills, and incineration (Ansah 2014). Between 30 and $50 \%$ of the local government budget is spent on waste collection and disposal, but can only collect a maximum of $80 \%$ of the waste generated, with the rest indiscriminately disposed of (Tchobanoglous and Kreith 2002).

The use of landfills and dumpsites are the main means of waste disposal in the country, with their attendant environmental and social issues, such as stench, toxic leachate, and land scarcity and neighbourhood revolt against the location of such facilities. While existing waste disposal facilities are lacking to manage the quality and quantity of waste produced, more sophisticated systems are costly and their maintenance prerequisites are high (Peter 2002).

The Ga West Municipality in the Greater Accra Region of Ghana used to be a significant hub for food crops production and marketing in the region. However, this situation has changed due to rampant land sales which have reduced land availability for agricultural purposes drastically. Further, soils of agricultural lands are degraded through topsoil removal by real estate practitioners, with a high rate of youth unemployment. The municipality, however, continues to host prominent markets where farm produce are brought for sale. This farm produces are becoming a source of waste in the municipality. Public and commercial places like markets and lorry stations are sources of significant volumes of waste generated in urbanized areas of Ghana. Markets, for instance, contribute between 15 and $20 \%$ of the total volume of waste generated in urbanized areas of Ghana. Baseline studies conducted by researchers from the University of Ghana as parts of the Municipality Utilization of Organic Waste to Improve Agricultural Productivity project revealed that out of the bulk of the estimated 55,900 tons of solid waste generated in the Ga West Municipality annually (Ghana Statistical Service 2014), 80-90\% of market waste is organic and highly putrescible (Annang and YirenyaTawiah 2015).

Strangely the waste management methods employed for treating and disposing of this organic waste type in the $\mathrm{Ga}$ West are mainly open and indiscriminate dumping and to a lesser extent land-filling (Ghana Statistical Service 2014). This method causes air pollution as well as leachate production (El-Fadel et al. 1997), with resultant effects on the environment and general health effects to waste handlers and the general public (Osei and Duker 2008; Yoada et al. 2014). Other means of disposal like aerobic composting and others like vermicomposting and waste-to-energy initiatives are non-existent.

Composting is a biological method whereby consistent introduction of air by mechanical turning rouses oxygenconsuming microorganism to diminish natural materials such as manure to a more steady material like humus (Rynk 1992). It is an appropriate method for reusing natural squanders in an ecologically benevolent way. Due to the sorts, nature, and composition of wastes in developing countries, composting remains the most sparing and proficient treatment technique among other treatment techniques (Singh et al. 2010; Taiwo 2011). Further to serving as a waste management strategy, composting organic waste will serve as a source of employment and revenue generation for the youth, farmers, and others who take part in the recovery, processing, and utilization chain (Gabbay 2010). It will also provide an environmentally sound alternative to inorganic fertilizer in replenishing farmlands, especially in cases where sourcesegregated organic waste are used to reduce the chances of toxic household chemicals getting infused into the compost produced, thereby introducing toxins into the soil and plants. However, the use of compost as solid waste management is no longer explored in Ga West. Thus, the study (1) determined physical and chemical properties of compost made of different raw materials in the market waste stream, and (2) analyzed the distribution of heavy metals and (3) assessed the quality of the compost through germination of seeds of some horticultural crops.

\section{Materials and methods}

\section{Study area}

The study was conducted in the Ga West Municipality, which is one of the sixteen (16) Metropolitan, Municipal, and Districts Assemblies (MMDAs) that form the Greater Accra Region of Ghana. The municipality lies within latitudes $50^{\circ} 48^{\prime}$ North and $5^{\circ} 39$ North, and longitudes $0^{\circ} 12^{\prime}$ West and $0^{\circ} 22^{\prime}$ West with a dry equatorial climate that experiences double maxima rainfall pattern which peaks in June and August. Average rainfall ranges from $750 \mathrm{~mm}$ in the south to about $1270 \mathrm{~mm}$ in the north, with the first season being from April to June and the second season being from August to November (Saka et al. 2013). The annual average temperature ranges between $25.1^{\circ} \mathrm{C}$ in August and $28.4^{\circ} \mathrm{C}$ in February and March. Humidity is generally high during the year. Average humidity figures are about $94 \%$ and 69\% at 06:00 and 15:00 h, respectively. The Municipality has a population of about 219,788 inhabitants with relatively more females (51.0\%) than males (49.0\%) (Ghana 
Statistical Service 2014). The Municipality has a total number of 55,913 households (Ghana Statistical Service 2014). The Municipality occupies a land area of approximately $299.578 \mathrm{~km}^{2}$ with about 412 communities.

Commerce, industry and agriculture are the dominant economic activities in the municipality, with about $6.9 \%$ of the population actively engaged in agriculture (Ghana Statistical Service 2012). The majority (77.6\%) of the farmers are involved in crop farming and less than one-quarter (23.5\%) are involved in livestock rearing. The main agricultural activities include cassava production, fishing, and pineapple production. Poultry (57.9\%) is the dominant animal reared in the Municipality.

\section{Experimental design}

Source-separated organic MSW was collected from three major markets in the municipality that was provided waste bins after a waste segregation sensitization drive. The segregated market waste, which was categorized into food waste and fruit waste, was composted in combination with other supplementary feedstock (saw dust, swine manure and rice straw) for a period of 15 weeks. The compost labels and feed stock combination are as follows:

- AS1-fruit waste:sawdust:swine manure

- AS2-fruit waste:sawdust:food waste:swine manure

- AD1—rice straw:food waste:fruit waste:swine manure

- AD2-rice straw:food waste:swine manure

Table 1 Feedstock and combination ratios

\begin{tabular}{lll}
\hline Pile & Feedstock & Ratios v/v \\
\hline AS1 & Fruit waste:sawdust:swine manure & $1: 1: 1$ \\
AS2 & Fruit waste:sawdust:food waste:swine manure & $1: 1: 1: 1$ \\
AD1 & Rice straw:food waste:fruit waste:swine manure & $1: 1: 1: 1$ \\
AD2 & Rice straw:food waste:swine manure & $1: 1: 1$ \\
\hline
\end{tabular}

The compost feedstock and combination ratio are provided in Table 1. The use of this combination ratio ensured that all compost piles were within the optimum carbon-tonitrogen ratio of between 25:1 and 35:1, based on preliminary laboratory assessment.

The chemical properties used in manufacturing the composts are listed in Table 2.

Compost piles were manually turned every 21 days. The moisture content of the pile was kept at $60 \%$ (Cooperband 2002) and covered with perforated polyethylene sheets to reduce moisture loss and protect piles from external water addition like rain. The experiment was carried out at the Compost Unit at the Ga West Municipality. Homogenized compost samples were taken from the top, middle, and bottom sections of each compost pile during the first turning and after composting, to determine the compost chemical properties. Samples were placed in polyethylene bags and transferred to the laboratory for analysis. The analysis was carried out at the University of Ghana Ecological Laboratory.

\section{Data analysis}

Physical and chemical properties including temperature, $\mathrm{pH}$, electrical conductivity (EC), total organic carbon, total organic matter, total nitrogen, total phosphorus, total potassium and $\mathrm{C} / \mathrm{N}$ ratio were analyzed.

$\mathrm{pH}$ and EC were measured by the sample in water (1:10) using $\mathrm{pH}$ metre and conductivity metre (Miaomiao et al. 2009). Organic carbon and organic matter were determined using the Walkley and Black (1934) procedure and Van Bemmelen factor. Phosphorus was analyzed using ascorbic acid method (Watanabe and Olsen 1965) and total nitrogen was determined by modified Kjeldahl's method (Bremner 1965). The concentrations of $\mathrm{NH}_{4}-\mathrm{N}$ and $\mathrm{NO}_{3}-\mathrm{N}$ were determined by extracting the sample with $2 \mathrm{~N} \mathrm{KC1}$ and the extracts were distilled using a steam distillation apparatus. $\mathrm{MgO}$ was added to the extract to remove the $\mathrm{NH}_{4}-\mathrm{N}$ from the sample. After the removal of $\mathrm{NH}_{4}-\mathrm{N}$, Devarda's alloy was added to determine
Table 2 Average ( \pm standard error) chemical properties of feedstock used for composting

\begin{tabular}{llllll}
\hline Parameter & Fruit waste & Market waste & Swine manure & Sawdust & Rice straw \\
\hline $\mathrm{pH}$ & $6.98 \pm 0.14$ & $7.60 \pm 0.04$ & $7.61 \pm 0.02$ & $6.02 \pm 0.20$ & $7.86 \pm 0.12$ \\
$\mathrm{EC}(\mu \mathrm{S} / \mathrm{cm})$ & $428.32 \pm 15.00$ & $521.51 \pm 21.58$ & $2912.20 \pm 10.01$ & $213.02 \pm 0.81$ & $198.34 \pm 2.11$ \\
$\mathrm{OC}(\%)$ & $23.34 \pm 1.60$ & $12.92 \pm 2.17$ & $18.68 \pm 1.03$ & $24.83 \pm 1.78$ & $24.44 \pm 1.96$ \\
$\mathrm{OM}(\%)$ & $40.25 \pm 1.63$ & $22.27 \pm 1.04$ & $32.20 \pm 2.05$ & $35.9 \pm 0.06$ & $42.14 \pm 1.01$ \\
$\mathrm{NO}_{3}-\mathrm{N}(\mathrm{mg} / \mathrm{kg})$ & $345.6 \pm 16.54$ & $172.80 \pm 6.29$ & $180.0 \pm 12.97$ & $180.0 \pm 9.62$ & $158.40 \pm 11.21$ \\
$\mathrm{NH}_{3}-\mathrm{N}(\mathrm{mg} / \mathrm{kg})$ & $363.6 \pm 10.20$ & $1317.60 \pm 98.85$ & $2980.80 \pm 56.28$ & $388.80 \pm 31.86$ & $619.20 \pm 28.73$ \\
$\mathrm{TN}(\%)$ & $0.71 \pm 0.04$ & $0.87 \pm 0.06$ & $1.10 \pm 0.04$ & $0.29 \pm 0.02$ & $0.32 \pm 0.02$ \\
$\mathrm{TK}(\%)$ & $0.17 \pm 0.01$ & $012 \pm 0.2$ & $0.10 \pm 0.01$ & $0.46 \pm 0.01$ & $0.15 \pm 0.02$ \\
$\mathrm{TP}(\%)$ & $0.28 \pm 0.04$ & $0.50 \pm 0.03$ & $0.62 \pm 0.07$ & $0.38 \pm 0.04$ & $0.30 \pm 0.04$ \\
$\mathrm{C} / \mathrm{N}$ ratio & 32.87 & 14.13 & 19.78 & 85.62 & 76.38 \\
\hline
\end{tabular}


the amount of $\mathrm{NO}_{3}-\mathrm{N}$ (Page et al. 1982). Heavy metals including nickel, chromium, copper, zinc, cadmium, lead, arsenic, mercury, and potassium were analyzed by digesting with perchloric acid (Gregorich and Carter 2007) and determined using Atomic Absorption Spectrometer-AAS (Perkin-Elmer Analyst 400). These parameters were determined after $1 \mathrm{~g}$ of each sample was digested, and the levels were calculated using the formula below:

Heavy metal concentration $(\mathrm{mg} / \mathrm{kg})=\frac{\text { Spectrometer Reading } \times 100}{1000 \times \text { Weight of sample }}$.

The extent of compost maturity can be assessed using various parameters such as $\mathrm{pH}, \mathrm{C} / \mathrm{N}$ ratio, organic matter loss, respiration analysis, and germination test (Delgado et al. 2002; Gómez et al. 2006; Ofosu-Budu et al. 2010). The assessment of compost phytotoxicity was carried using a germination test as in Mitelut and Popa (2011) and Warman (1999). Compost extracts were prepared by mixing air-dried compost sample and distilled water in the ratio $1: 10(\mathrm{w} / \mathrm{v})$ as follows. Ten grams of compost was added to $100 \mathrm{ml}$ of distilled water. The mixture was shaken vigorously for about $30 \mathrm{~min}$ and filtered to generate the compost extract to be used in seed germination tests. Brassica oleracea var. capitata (cabbage), Solanum lycopersicum (tomatoes), and Cucumis sativus (cucumber) seeds were acquired from Agrimat Company Limited (viability as tested $=90 \%$ ) for the germination test. Ten (10) viable seeds were placed in a petri dish, which was lined with a filter paper, the setup moistened with $10 \mathrm{ml}$ of the appropriate compost extract. A similar setup with distilled water served as the control. The setup was prepared in triplicates and kept in the laboratory at room temperature. After 7 days of incubation, germinated seeds were counted and root length measured (Mitelut and Popa 2011; Warman 1999). The responses to the compost treatments were calculated by a germination index (GI) based on the formula below (Chen et al. 2010):

GI $(\%)=\frac{\% \text { Seed germination } \times \text { Root Length of Treatment }}{\% \text { Seed germination } \times \text { Root Length of Control }} \times 100$.

\section{Statistical analysis}

The differences in chemical properties between four combination ratios were assessed using one-way ANOVA followed by the comparison of means based on the Tukey HSD test. Statistical analyses were performed with SPSS version 20 and statistical mean differences were considered significant at $p<0.05$. Descriptive analysis was used to determine the phytotoxicity of the matured composts.

\section{Results and discussion}

\section{Compost temperature}

All compost piles recorded temperatures of $38{ }^{\circ} \mathrm{C}$ slightly above the recorded ambient temperature of $34^{\circ} \mathrm{C}$ at the start of composting (Fig. 1). During the composting period, all piles went through the three temperature phases required for effective sanitization (CCME 2005; Eusufzai et al. 2013) of the feedstock and efficiency of the process; the mesophilic phase where temperatures are between 15 and $45^{\circ} \mathrm{C}$; the thermophilic phase with temperatures between 45 and $70{ }^{\circ} \mathrm{C}$; and cooling phase when the pile temperatures drop below $60{ }^{\circ} \mathrm{C}$. Within a week of composting, all compost piles recorded temperature above $50{ }^{\circ} \mathrm{C}$. The mean temperature recorded after the first week of composting ranged from a minimum of $60{ }^{\circ} \mathrm{C}$ recorded for AS1 (combination of fruit waste:sawdust:swine manure) to a maximum temperature of $69{ }^{\circ} \mathrm{C}$ recorded for AS2 (combination of fruit waste:sawdust:food waste:swine manure). AD1 (combination of rice straw:food waste:fruit waste:swine manure) and AD2 (combination of rice straw:food waste:swine manure) recorded a mean temperature of $68^{\circ} \mathrm{C}$ after the first week of composting. There was a general gradual decline in temperature in the piles as composting progressed, but all piles experienced slight increase in temperature after turning. After the first turning regime, 3 weeks after composting, AS1 and AS2 recorded mean temperature increase of $6{ }^{\circ} \mathrm{C}$ (from 48 to $54{ }^{\circ} \mathrm{C}$ ), while $\mathrm{AD} 1$ and $\mathrm{AD} 2$ recorded mean temperature increases of $4{ }^{\circ} \mathrm{C}$ and $1{ }^{\circ} \mathrm{C}$, respectively. In general, AS1 and AS2 recorded higher mean temperature of over $45^{\circ} \mathrm{C}$ for a longer period of 11 weeks during the composting period, compared to AD1 and AD2 whose temperature remained below $45{ }^{\circ} \mathrm{C}$ after the seventh week of composting till the end of the composting process. The temperature of piles

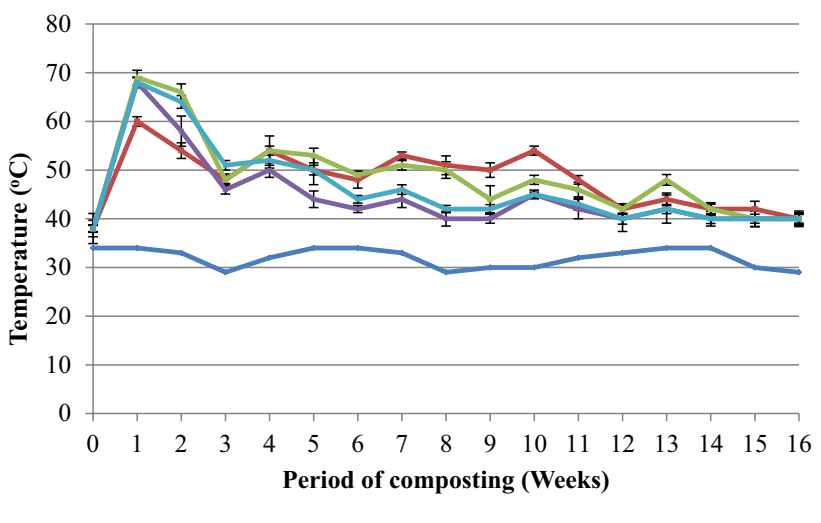

- AMBIENT TEMP $-\mathrm{AS} 1-\mathrm{AS} 2-\mathrm{AD} 1-\mathrm{AD} 2$

Fig. 1 Weekly mean temperature of compost piles during composting 
$\mathrm{AD} 1$ and $\mathrm{AD} 2$ were stable at a mean temperature of $40{ }^{\circ} \mathrm{C}$ from the 14th week through to the end of the composting period, while temperature of AS1 and AS2 continued to decline. The mean temperature of all the piles was stable at $40{ }^{\circ} \mathrm{C}$ after 15 weeks of composting.

The observed variation in periods of high temperature could be attributed to the variation in the bulking agents used (Himanen and Hänninen 2011), as AD1 and AD2 were composed of rice straw while AS1 and AS2 contained sawdust which has high lignin content and also a prolonged decomposition period, compared to rice straw which is degraded in relatively shorter time (Eusufzai et al. 2013). Similar temperature dynamics observed in AS1 and AS2 have been reported with a slight difference in the duration of thermophilic temperatures by (Huang et al. 2004), who used sawdust as a bulking agent in composting swine manure and recorded 6-week period of thermophilic temperatures.

\section{Chemical properties of compost}

$\mathrm{pH}$ of the compost piles ranged between 7.14 and 8.29, at the initial composting stage (Table 3 ). There was a general decline in $\mathrm{pH}$ at the end of the composting period. The decline in $\mathrm{pH}$ recorded at the end of the composting could be due to the volatilization of ammoniacal nitrogen and hydrogen ions $\left(\mathrm{H}^{+}\right)$release through the nitrification activities of nitrifying bacteria, as well as the emission of large volumes of carbon dioxide (Huang et al. 2004; Roca-Pérez et al.
2009). AS1 and AS2, however, recorded significantly lower $\mathrm{pH}$ than $\mathrm{AD} 1$ and $\mathrm{AD} 2$ throughout the composting period, an occurrence which could likely be due to the low $\mathrm{pH}$ of sawdust used as a bulking agent in AS1 and AS2, whereas rice straw, used in $\mathrm{AD} 1$ and $\mathrm{AD} 2$, had an alkaline $\mathrm{pH}$.

EC decreased from 1996 to $1472 \mu \mathrm{S} / \mathrm{cm}, 1926-1494.3$ $\mu \mathrm{S} / \mathrm{cm}, 2152-1828.6 \mu \mathrm{S} / \mathrm{cm}$ and $2102-1764.3 \mu \mathrm{S} / \mathrm{cm}$ in AS1, AS2, AD1 and AD2, respectively over the composting period. Our result is in line with Rashad et al. (2010), who attributed the observed decreasing trend to the precipitation of mineral salts and release of ammonia over the course of composting. The EC recorded for all compost piles in the study were well below the $4000 \mu \mathrm{S} / \mathrm{cm}$ maximum limit stated by Diacono and Montemurro (2015) as being needed to sustain plant growth and remediate saline soils. The EC values were similar to an average value of $2165 \mu \mathrm{S} / \mathrm{cm}$ reported by Nartey (2013) who co-composted cocoa husk and faecal sludge. Similar results also found by Moldes et al. (2007) who composted municipal solid waste in Spain and found $2300 \mu \mathrm{S} / \mathrm{cm}$. Low soluble salt levels $(\mathrm{EC}<3.5 \mathrm{dS} / \mathrm{m})$ are preferable for potting compost (Noguera et al. 2003). Low values indicate a lack of available salts, while high values indicate a large number of soluble salts that may inhibit biological activity or may be unsuitable for land application if large quantities of the material are used.

Organic carbon (OC) content of compost piles generally decreased over the composting period. After the third week of composting, the organic carbon content of the
Table 3 Average ( \pm standard error) chemical properties of compost piles

\begin{tabular}{lllllll}
\hline Parameter & Age & AS1 & AS2 & AD1 & AD2 & $p$ value \\
\hline pH & Week 3 & $7.2 \pm 0.2$ & $7.15 \pm 0.11$ & $8.10 \pm 0.06$ & $8.28 \pm 0.02$ & \\
& Week 15 & $7.1 \pm 0.16^{\mathrm{b}}$ & $7.13 \pm 0.06^{\mathrm{b}}$ & $7.42^{\mathrm{b}} \pm 0.04$ & $8.20^{\mathrm{a}} \pm 0.18$ & $0.000^{*}$ \\
$\mathrm{EC}(\mu \mathrm{S} / \mathrm{cm})$ & Week 3 & $1996 \pm 47.60$ & $1926 \pm 18.2$ & $2152 \pm 12.4$ & $2102 \pm 10.8$ & \\
& Week 15 & $1472.67^{\mathrm{c}} \pm 12.7$ & $1494.3^{\mathrm{c}} \pm 5.1$ & $1828.67^{\mathrm{a}} \pm 10.26$ & $1764.3^{\mathrm{b}} \pm 4.1$ & $0.000^{*}$ \\
$\mathrm{OC}(\%)$ & Week 3 & $21.26 \pm 1.94$ & $22.06 \pm 1.4$ & $20.26 \pm 2.73$ & $21.64 \pm 1.87$ & \\
& Week 15 & $28.21^{\mathrm{c}} \pm 0.35$ & $27.1^{\mathrm{d}} \pm 0.4$ & $31.1^{\mathrm{a}} \pm 0.46$ & $29.97^{\mathrm{b}} \pm 0.4$ & $0.001^{*}$ \\
$\mathrm{OM}(\%)$ & Week 3 & $36.22 \pm 1.62$ & $38.5 \pm 1.9$ & $34.94 \pm 0.66$ & $36.65 \pm 1.43$ & \\
& Week 15 & $48.63^{\mathrm{c}} \pm 0.61$ & $46.63^{\mathrm{d}} \pm 0.69$ & $53.56^{\mathrm{a}} \pm 0.79$ & $51.67^{\mathrm{b}} \pm 0.69$ & $0.000^{*}$ \\
$\mathrm{NO} 3^{-\mathrm{N}}(\mathrm{mg} / \mathrm{kg})$ & Week 3 & $151.20 \pm 8.14$ & $175.00 \pm 5.12$ & $231.20 \pm 6.87$ & $216.0 \pm 11.03$ & \\
& Week 15 & $237.22^{\mathrm{a}} \pm 38.11$ & $168.27^{\mathrm{b}} \pm 28.87$ & $221.83^{\mathrm{ab}} \pm 18.41$ & $207.40^{\mathrm{ab}} \pm 2.42$ & $0.052^{*}$ \\
$\mathrm{NH} 4^{-\mathrm{N}}(\mathrm{mg} / \mathrm{kg})$ & Week 3 & $712.80 \pm 11.28$ & $766.70 \pm 4.01$ & $426.30 \pm 24.07$ & $345.60 \pm 4.69$ & \\
& Week 15 & $237.22^{\mathrm{a}} \pm 38.11$ & $168.27^{\mathrm{b}} \pm 28.87$ & $221.83^{\mathrm{ab}} \pm 18.41$ & $207.40^{\mathrm{ab}} \pm 2.42$ & $0.052^{*}$ \\
$\mathrm{TN}(\%)$ & Week 3 & $0.68 \pm 0.00$ & $0.69 \pm 0.01$ & $0.64 \pm 0.03$ & $0.62 \pm 0.03$ & \\
& Week 15 & $0.97^{\mathrm{a}} \pm 0.11$ & $0.77^{\mathrm{a}} \pm 0.16$ & $0.93^{\mathrm{a}} \pm 0.22$ & $0.96^{\mathrm{a}} \pm 0.09$ & 0.392 \\
$\mathrm{TK}(\%)$ & Week 3 & $0.03 \pm 0.01$ & $0.03 \pm 0.01$ & $0.13 \pm 0.1$ & $0.15 \pm 0.02$ & \\
& Week 15 & $0.39^{\mathrm{b}} \pm 0.04$ & $2.30^{\mathrm{a}} \pm 1.30$ & $0.71^{\mathrm{ab}} \pm 0.02$ & $0.79^{\mathrm{ab}} \pm 0.31$ & $0.032^{*}$ \\
$\mathrm{TP}(\%)$ & Week 3 & $0.38 \pm 0.02$ & $0.49 \pm 0.01$ & $0.36 \pm 0.03$ & $0.29 \pm 0.04$ & \\
& Week 15 & $0.20^{\mathrm{b}} \pm 0.02$ & $0.33^{\mathrm{b}} \pm 0.04$ & $0.63^{\mathrm{b}} \pm 0.05$ & $1.87^{\mathrm{a}} \pm 0.37$ & $0.000^{*}$ \\
$\mathrm{C} / \mathrm{N}$ ratio & Week 3 & $31.26 \pm 1.27$ & $31.97 \pm 2.03$ & $31.66 \pm 2.64$ & $34.90 \pm 1.35$ & \\
& Week 15 & $20.13^{\mathrm{a}} \pm 2.87$ & $20.51^{\mathrm{a}} \pm 7.78$ & $18.02^{\mathrm{a}} \pm 9.17$ & $20.34^{\mathrm{a}} \pm 3.07$ & 0.544 \\
\hline \multirow{2}{*}{ (\% } & & & & &
\end{tabular}

Levels not connected by the same letter are significantly different 
compost piles ranged from a minimum of $20.26 \%$ recorded in $\mathrm{AD} 1$, and a maximum mean of $22.06 \%$ recorded in AS2 (Table 3). Pile AS1 and AD2 recorded initial OC of $21.26 \%$ and $21.64 \%$, respectively, over the same period. After 15 weeks of composting, AD2 recorded the highest mean OC of $19.32 \%$, while AS2 recorded the lowest mean OC of $17.02 \%$. AS1 and AD1 recorded organic carbon content of $18.32 \%$ and $18.20 \%$, respectively, (Table 3). Our result is similar as compared to Moldes et al. (2007). However, our result is fairly higher as compared to Khater (2015). The decline in OC during composting might be as a result of microbial decomposition of organic substrates (Bernal et al. 2009), which was evident of temperature increases during composting as microorganism consume carbon for energy. Dry matter loss in the form of carbon dioxide due to microbial activities and moisture evaporation similarly could account for the decline in organic matter over the composting period. This conforms to the results reported by Sangodoyin and Amori (2013). A decrease of OC was served as an indicator of compost maturity and stability (Garcia et al. 1991; Inbar et al. 1993; Zheng et al. 2007).

Total nitrogen values recorded for the experimental period increased by end of the composting period. Similar trends were observed in Al-Bataina et al. (2016) indicated nitrogen content of compost increased with increase in compost age. The total nitrogen content of the matured compost was between 0.7 and $1 \%$. These results are similar to those obtained by Benito et al. (2005) who found that the total nitrogen rate ranged from 0.99 to $2.01 \%$. However, our results are fairly low as compared to the result of Moldes et al. (2007). The increase in nitrogen could be attributed to a concentration effect as a result of substantial degradation of organic carbon compounds (Said-Pullicino et al. 2007), and the contribution of nitrogen-fixing bacteria (Huang et al. 2004). Total nitrogen (TN) level in AD1 and AD2 at the end of the study were higher than those of AS1 and AS2 likely as a result of minimal gaseous exchange within $\mathrm{AD} 1$ and $\mathrm{AD} 2$ due to compaction of the piles as rice straw used as bulking agent decomposed rapidly, compared to wood shaving and sawdust which were slow to decompose and enhanced aeration and nitrogen loss in AS1 and AS2.

The total potassium (TK) content of all the piles increased as the piles shrunk in size. A similar result was observed in Khater (2015). Significantly lower value of total potassium was found for AS1 compost and the highest value of total potassium was found for AS2 compost. AS1 and AD2 recorded decreased TK content from the 12th week to the 15 th week, which might be due to loss of potassium salts through excessive leaching (Chatterjee et al. 2013; Sommer 2001). The excessive leaching might have been due to excess moisture emanating from fruit waste beyond the absorption capacity of the bulking agents (Chatterjee et al. 2013).
The total phosphorus (TP) content of the piles increased throughout the composting period (Table 3). A similar result was observed in Khater (2015). This could be due to precipitation of phosphorus (P) in solid forms which could not be easily dissolved and leached out. This observation compares favourably results reported by Sommer (2001), whose recorded increasing phosphorus concentration was attributed to precipitation of $\mathrm{P}$ in solid form and shrinking organic matter content. Phosphorus concentration, therefore, increased as organic matter decreased over the composting period. Significantly lower value of total phosphorus was found for AS1 compost and the highest value of total phosphorus was found for AD2 compost (Table 3).

The initial $\mathrm{C} / \mathrm{N}$ ratios of the piles (31-34.9) were above the optimum range (25-30) recommended for efficient composting (Table 3). These were, however, below the ratio reported by Qian et al. (2014) who recorded the initial C/N ratio between 35 and 40 . The high initial $\mathrm{C} / \mathrm{N}$ ratio recorded was due to the high carbon content of the bulking agents (sawdust and rice straw) used. Nitrogen loss through ammonia emission during the first 2 weeks of composting might also be responsible for the high initial $\mathrm{C} / \mathrm{N}$ ratio recorded, as the initial $\mathrm{C} / \mathrm{N}$ ratio reading was taken in the third week of composting. The $\mathrm{C} / \mathrm{N}$ ratio of $\mathrm{AD} 1$ and $\mathrm{AD} 2$, which assumed similar trend during the composting process likely due to the near similar feedstock combination, progressively decreased from the sixth week to the end of the composting period likely as a result of difference in the labile nature of carbon in rice straw and sawdust. At the end of the study, the initial $\mathrm{C} / \mathrm{N}$ ratios of the piles reduced from $31.26,31.97,31.66$, and 34.90-20.13, 20.51, 18.02, and 20.34 for piles AS1, AS2, $\mathrm{AD} 1$ and $\mathrm{AD} 2$, respectively. The reduced $\mathrm{C} / \mathrm{N}$ ratio at the end of composting period observed in this study is in line with the study of Al-Bataina et al. (2016) who stated C/N ratio decreased with increase in compost age. These were indicative of reduction in carbon content of the treatments by microbe activities, as well as evolution of nitrogen. Increases in nitrogen level were observed for all treatment, from the 9th week in AD1 and AD2 and from the 12th week in AS1 and AS2, likely products of microbial protein which led to the observed decline in $\mathrm{C} / \mathrm{N}$ ratios. The relatively high final $\mathrm{C} / \mathrm{N}$ ratios recorded in the piles confirm the observation of Qian et al. (2014) that higher initial C/N ratios (35-40) result in compost with final $\mathrm{C} / \mathrm{N}$ ratio close to 25 .

Ammoniacal nitrogen $\left(\mathrm{NH}_{4}-\mathrm{N}\right)$ content of the matured compost was between 0.7 and $1 \%$ (Table 3 ). Significantly higher $\mathrm{NH}_{4}-\mathrm{N}$ was recorded in AS1 while lower $\mathrm{NH}_{4}-\mathrm{N}$ was found in AS2. $\mathrm{NH}_{4}-\mathrm{N}$ levels generally decreased in the course of composting, beginning with very high levels at early active phase of composting where organic nitrogen is rapidly decomposed (Nakhshiniev et al. 2014). Similarly, Al-Bataina et al. (2016) and Larney et al. (2008) found $\mathrm{NH}_{4}-\mathrm{N}$ decreased with the increase in compost age. 
Through volatilization and nitrification, the $\mathrm{NH}_{4}-\mathrm{N}$ level is reduced during the maturity phase. By the end of the composting period, stable $\mathrm{NH}_{4}-\mathrm{N}$ levels were observed, with AS2 and AD2 recording relatively early stable levels from the sixth week and ninth week, respectively, through to the end of composting. The $\mathrm{NH}_{4}-\mathrm{N}$ levels (176.4-230.92 mg/ $\mathrm{kg}$ ) observed at the end of the study were well below the $500 \mathrm{mg} / \mathrm{kg}$ maximum concentration standard for matured compost proposed by the (CCME 2005). El Fels et al. (2014) and Nakhshiniev et al. (2014) reported similar $\mathrm{NH}_{4}-\mathrm{N}$ trend in their studies. However, the final results of $\mathrm{NH}_{4}-\mathrm{N}$ in this study were above those reported by Nakhshiniev et al. (2014) who composted rice straw in an enclosed reactor.

Nitrate- $\mathrm{N}\left(\mathrm{NO}_{3}-\mathrm{N}\right)$ production, an indication of nitrification, occurs during the curing stage of composting where the temperature is below $40{ }^{\circ} \mathrm{C}$ (Bernal et al. 2009). The rate of $\mathrm{NO}_{3}-\mathrm{N}$ production further depends on the level of $\mathrm{NH}_{4}-\mathrm{N}$ available in the compost for nitrifying bacteria to act on. Significantly highest $\mathrm{NO}_{3}-\mathrm{N}$ was recorded in AS1 as compared to the other compost piles. A decline in $\mathrm{NO}_{3}-\mathrm{N}$ was observed in $\mathrm{AS} 2, \mathrm{AD} 1$, and $\mathrm{AD} 2$ at the end of the composting period. The decline in $\mathrm{NO}_{3}-\mathrm{N}$ levels at the end of composting period observed in AS2, AD1 and AD2 (Table 3) could be due to leaching as this was the period of active degradation with excess moisture seepage (Sommer 2001). The composting system used in the study made no provision for leachate collection and return to the pile, and might have resulted in $\mathrm{NO}_{3}-\mathrm{N}$ loss over this period. The increase in $\mathrm{NO}_{3}-\mathrm{N}$ level observed in AS1 throughout the composting period was probably due to nitrification, since $\mathrm{NH}_{4}-\mathrm{N}$ concentration of this pile decreased during this period (Al-Bataina et al. 2016). This might have been due to the low $\mathrm{pH}$ values recorded over the composting period due to low $\mathrm{pH}$ of fruit waste used which favoured nitrifying bacteria.

\section{Heavy metal concentration}

Heavy metal concentration in compost is one of the main factors that restrict marketing and use due to bioaccumulation potential of these metals. Analysis of compost samples showed the presence of all eight (8) heavy metals: nickel, chromium, copper, zinc, cadmium, lead, arsenic, and mercury (Table 4).

$\mathrm{Ni}$ and As content of the piles decreased throughout the composting period, which was in agreement with Hanc et al. (2012) and Larney et al. (2008). The observed quantitative changes in $\mathrm{Ni}$ and $\mathrm{As}$ in the compost chemical fractions might be affected by biochemical-microbial transformations taking place in the course of composting of the organic matter (Jakubus and Czekała 2010). In contrary, Cr, Zn, Cd and $\mathrm{Pb}$ content of the piles increased throughout the composting period. Similar result was observed in Pascual et al. (1997) which showed that $\mathrm{Zn}$ and $\mathrm{Pb}$ content of compost increased. Previous studies have demonstrated that the composting and maturation processes increase insolubility of metals which become less available to plants (García et al. 1990). Cu content of the piles showed different trends. $\mathrm{Cu}$ content in AS1 and AS2 showed a decline throughout the composting period while AD1 and AD2 showed an increasing trend. The increase in concentration of $\mathrm{Cu}$ throughout the composting
Table 4 Average ( \pm standard error) heavy metal concentration in compost

\begin{tabular}{llrrrrr}
\hline $\begin{array}{l}\text { Element } \\
(\mathrm{mg} / \mathrm{kg})\end{array}$ & Age & \multicolumn{1}{l}{ AS1 } & \multicolumn{1}{l}{ AS2 } & \multicolumn{1}{l}{ AD1 } & \multicolumn{1}{l}{ AD2 } & $p$ value \\
\hline Nickel (Ni) & Week 3 & $31.25 \pm 1.30$ & $38.11 \pm 0.96$ & $29.45 \pm 1.28$ & $29.66 \pm 1.11$ & \\
& Week 15 & $26.89^{\mathrm{a}} \pm 6.71$ & $27.24^{\mathrm{a}} \pm 1.96$ & $26.73^{\mathrm{a}} \pm 0.81$ & $32.67^{\mathrm{a}} \pm 0.55$ & 0.915 \\
Chromium (Cr) & Week 3 & $14.40 \pm 4.14$ & $15.30 \pm 3.67$ & $13.80 \pm 1.33$ & $13.99 \pm 2.25$ & \\
& Week 15 & $28.47^{\mathrm{b}} \pm 6.10$ & $26.02^{\mathrm{b}} \pm 1.41$ & $37.37^{\mathrm{ab}} \pm 3.02$ & $44.75^{\mathrm{a}} \pm 9.84$ & $0.018^{*}$ \\
Copper (Cu) & Week 3 & $17.15 \pm 2.81$ & $17.30 \pm 0.57$ & $12.30 \pm 2.47$ & $14.00 \pm 0.72$ & \\
& Week 15 & $15.23^{\mathrm{a}} \pm 0.40$ & $16.88^{\mathrm{a}} \pm 5.10$ & $22.30^{\mathrm{a}} \pm 6.41$ & $23.36^{\mathrm{a}} \pm 2.29$ & 0.121 \\
Zinc (Zn) & Week 3 & $16.65 \pm 2.12$ & $18.60 \pm 0.89$ & $11.25 \pm 2.31$ & $12.00 \pm 0.16$ & \\
& Week 15 & $30.16^{\mathrm{a}} \pm 5.01$ & $39.63^{\mathrm{a}} \pm 4.05$ & $34.38^{\mathrm{a}} \pm 2.27$ & $35.11^{\mathrm{a}} \pm 3.65$ & 0.126 \\
Cadmium (Cd) & Week 3 & $0.20 \pm 0.02$ & $0.20 \pm 0.01$ & $0.10 \pm 0.00$ & $0.09 \pm 0.00$ & \\
& Week 15 & $1.36^{\mathrm{b}} \pm 0.53$ & $1.67^{\mathrm{ab}} \pm 0.12$ & $1.93^{\mathrm{a}} \pm 0.12$ & $1.61^{\mathrm{ab}} \pm 0.19$ & $0.004^{*}$ \\
Lead (Pb) & Week 3 & $19.25 \pm 0.68$ & $21.68 \pm 1.12$ & $16.55 \pm 2.02$ & $15.21 \pm 1.18$ & \\
& Week 15 & $19.33^{\mathrm{b}} \pm 2.58$ & $39.40^{\mathrm{a}} \pm 1.31$ & $23.06^{\mathrm{b}} \pm 6.04$ & $15.90^{\mathrm{b}} \pm 4.41$ & $0.000^{*}$ \\
Arsenic (As) & Week 3 & $0.68 \pm 0.03$ & $0.97 \pm 0.01$ & $1.26 \pm 0.20$ & $1.62 \pm 0.04$ & \\
& Week 15 & $0.41^{\mathrm{c}} \pm 0.02$ & $0.30^{\mathrm{d}} \pm 0.03$ & $0.80^{\mathrm{a}} \pm 0.03$ & $0.52^{\mathrm{b}} \pm 0.05$ & $0.000^{*}$ \\
Mercury (Hg) & Week 3 & $0.64 \pm 0.00$ & $0.65 \pm 0.01$ & $0.54 \pm 0.01$ & $0.57 \pm 0.02$ & \\
& Week 15 & $0.27^{\mathrm{c}} \pm 0.02$ & $0.37^{\mathrm{a}} \pm 0.02$ & $0.31^{\mathrm{bc}} \pm 0.01$ & $0.33^{\mathrm{ab}} \pm 0.03$ & $0.002^{*}$ \\
\hline
\end{tabular}

Levels not connected by the same letter are significantly different 
period in $\mathrm{AD} 1$ and $\mathrm{AD} 2$ might be due to progressive mineralization of organic matter within the compost, and loss through respiration over time (Amir et al. 2005). Significantly highest $\mathrm{Cr}$ was found in AD2 $(44.75 \mathrm{mg} / \mathrm{kg})$ as compared to the other compost types. In contrary, lower chromium was recorded in AS2 $(26.02 \mathrm{mg} / \mathrm{kg})$. Arsenic content significantly varied among the compost piles, with the highest recorded in AD1 $(0.80 \mathrm{mg} / \mathrm{kg})$, and lowest in AS2 $(0.3 \mathrm{mg} / \mathrm{kg})$. Significantly higher Cd was recorded in AD2 while lower cadmium was observed in AS1. Significant differences were also observed in $\mathrm{Pb}$ and $\mathrm{Hg}$ content of the different compost piles (Table 4). Zn was reported as the most abundant heavy metal in the source-separated municipal solid waste as observed in other studies (Wong et al. 2001; Zheljazkov and Warman 2004).

Ni $(26.73-32.67 \mathrm{mg} / \mathrm{kg}), \mathrm{Cr}(26.02-44.75 \mathrm{mg} / \mathrm{kg})$, $\mathrm{Cu}(15.23-23.36 \mathrm{mg} / \mathrm{kg}), \mathrm{Zn}(30.16-39.63 \mathrm{mg} / \mathrm{kg}), \mathrm{Cd}$ (1.36-1.93 mg/kg), Pb (15.9-39.4 mg/kg), As (0.30-0.8 mg/ $\mathrm{kg})$ and $\mathrm{Hg}(0.27-0.37 \mathrm{mg} / \mathrm{kg})$ concentration in the composts produced were within the Canadian Compost Quality standards (CCME 2005), and European Union and USA Biosolids ranges (Brinton 2004) (Table 5). This implies that these materials can be used in Agriculture. However, longterm application of compost may also have some negative effects on the agricultural environment due to their metal content if not managed correctly (Achiba et al. 2009). As compared to Moldes et al. (2007) and Cherif et al. (2009), our results were fairly low. The low concentration of heavy metals recorded in the compost was probably due to the source separation of the feedstock which reduced the chance of heavy metal contamination. This confirms the observation of Ofori (2013) that source separation of feedstock accounts for low concentration of heavy metals in compost. It has been suggested that a reason for the decrease in heavy metal concentration and mobility is due to the bioaccumulation of earthworms within their tissue through gut/skin absorption (Liu et al. 2012); and with overloaded metal burdens, the earthworm tissues tend to be decomposed, rendering these elements even higher availability (Ma et al. 2003).

Table 5 Heavy metal standards for Europe, USA, and Canada Source: Canadian Council of Ministers of the Environment (CCME 2005) and Brinton (2004)

\begin{tabular}{lccl}
\hline Element & EU Range & USA Biosolids & CCME \\
\hline Cadmium (mg/kg) & $0.7-10$ & 39 & $3-20$ \\
Chromium (mg/kg) & $70-200$ & 1200 & 210 \\
Copper $(\mathrm{mg} / \mathrm{kg})$ & $70-600$ & 1500 & 400 \\
Mercury $(\mathrm{mg} / \mathrm{kg})$ & $0.7-10$ & 17 & $0.8-5$ \\
Nickel $(\mathrm{mg} / \mathrm{kg})$ & $20-200$ & 420 & $62-180$ \\
Lead $(\mathrm{mg} / \mathrm{kg})$ & $70-1000$ & 300 & $150-500$ \\
Zinc $(\mathrm{mg} / \mathrm{kg})$ & $210-4000$ & 2800 & $700-1850$ \\
\hline
\end{tabular}

\section{Phytotoxicity of the matured composts}

The germination test has been used to evaluate the compost maturity and phytotoxicity of biowastes (Roe et al. 1997). Germination tests carried out to assess phototoxicity of the composts showed that cucumber and cabbage recorded $100 \%$ germination in all the treatments at the end of the experimentation period (Fig. 2). Tomato recorded 80\% germination in AS1 and AD1 extracts, while both AS2 and AD2 recorded $70 \%$ germination. The control recorded mean germination of $80 \%$. The difference in the germination rate between the plant species might be due to seed sensitivity. Similar results were observed in Tiquia and Tam (1998) who found germination between 80 and $100 \%$. Pascual et al. (1997) also found that a germination rate between 80 and $90 \%$ in mature composts.

Germination indices (GI) of tomato in water extracts of composts from the four different feedstock combinations ranged from a minimum of $80 \%$ recorded for AS2, to a maximum of $99 \%$ recorded for AS1 (Fig. 3). Similar results were also found in Pampuro et al. (2017) and Tiquia et al. (1996). Selim et al. (2012) also found greater than 80\% (81.88-97.46) GI of Lepidium sativum. The germination indices of cucumber seeds ranged from a minimum of $170 \%$ recorded for AS2 extract, to a maximum of $198 \%$ recorded for AD2 extract (Fig. 3). Similarly, Pampuro et al. (2017) found a GI of 160.7, 187.9, 200.9 and 264.4\% for $L$. sativum in four different compost types. The high GI obtained in this study might be due to the presence of adequate amounts of $\mathrm{NH}_{4}{ }^{+}$and other nutrients in composts extracts (Romero et al. 2013). If GI values are greater than $80 \%$, the compost is assumed as phytotoxin-free (Zucconi 1981). In this study all compost piles showed GI values higher than this limit and, therefore, they can be considered phytotoxin-free.

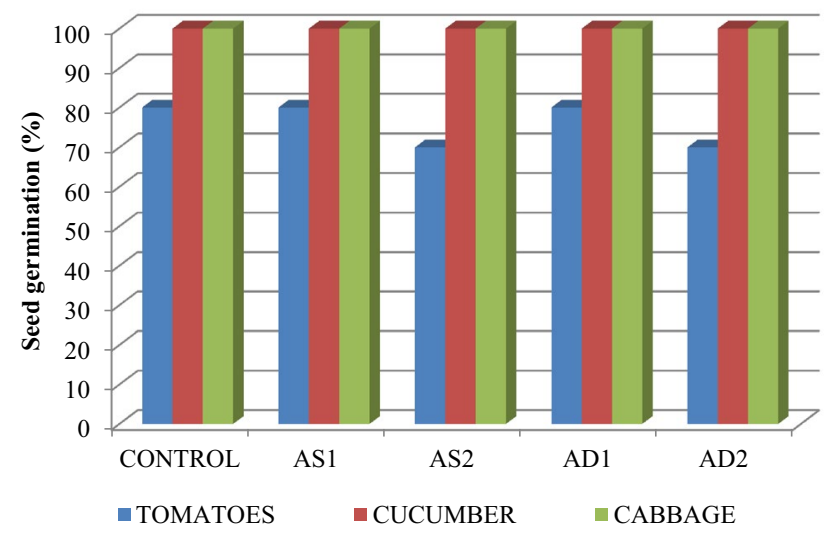

Fig. 2 Percentage seed germination in compost extracts and deionized water 


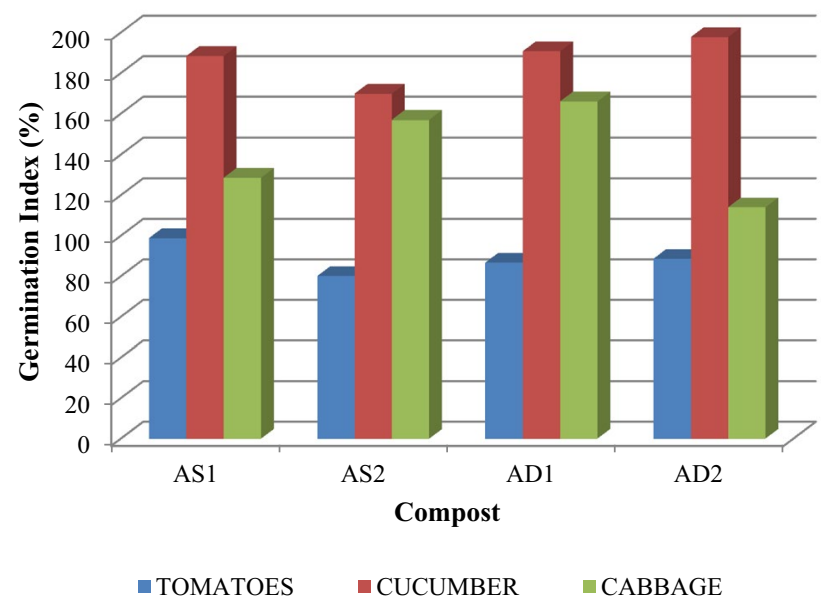

Fig. 3 Germination indices of tomato, cucumber, and cabbage seeds in compost extracts

\section{Conclusion}

It was observed that the final compost quality parameters met international compost standard. The different feedstock combination attained reduced $\mathrm{N}$-loss, appreciable total NPK levels, and very low heavy metal concentration. High germination index (80-198\%) recorded for the various compost mixes indicated that the composts produced would be suitable for cultivation of vegetable, especially cucumber. The result of this study suggests that compost from MSW with different materials as bulking agents after 15 weeks of composting are phytotoxic-free. Therefore, it can be concluded that the four composts could be used for organic vegetable production and other food crops without risk on seed germination and plant growth. Building on the foundation of compost produced from segregated waste from the market in the Ga West municipality having good agricultural values, diversion of the organic component of waste generated in similar commercial centres, where sorted from source, can be a good candidate for composting to reduce the volume of waste. Research should be undertaken to determine the rate of compost application for the cultivation of specific crops to inform farmers on optimum usage. This should be backed with information on current soil characteristic and qualities in the Ga West municipality to determine the most suitable compost combinations for specific soils. Further studies are also needed to determine and map out zones of consumers who are willing and are with actual capacity to pay premium prices for organic crops produced with compost. This will create viable organic markets and indirectly promote composting of waste in the Ga West municipality, thereby increasing waste utilization.
Acknowledgements We thank to the sponsors of this study, Management for Development Foundation (MDF), through financial support from the Netherlands Ministry of Foreign Affairs, and the Utilization of Organic Waste in Agricultural Productivity (UOWIAP) project. We also acknowledge University of Ghana. We are grateful to the three anonymous referees for constructive comments on an earlier version of this manuscript.

\section{Compliance with ethical standards}

Conflicts of interest The authors declare no conflict of interest.

Open Access This article is distributed under the terms of the Creative Commons Attribution 4.0 International License (http://creativeco mmons.org/licenses/by/4.0/), which permits unrestricted use, distribution, and reproduction in any medium, provided you give appropriate credit to the original author(s) and the source, provide a link to the Creative Commons license, and indicate if changes were made.

\section{References}

Achiba WB, Gabteni N, Lakhdar A, Laing GD, Verloo M, Jedidi N, Gallali T (2009) Effects of 5-year application of municipal solid waste compost on the distribution and mobility of heavy metals in a Tunisian calcareous soil. Agric Ecosyst Environ 130:156-163. https://doi.org/10.1016/j.agee.2009.01.001

Al-Bataina BB, Young TM, Ranieri E (2016) Effects of compost age on the release of nutrients. ISWCR 4:230-236. https://doi. org/10.1016/j.iswcr.2016.07.003

Amir S, Hafidi M, Merlina G, Revel J-C (2005) Sequential extraction of heavy metals during composting of sewage sludge. Chemosphere 59:801-810. https://doi.org/10.1016/j.chemosphere.2004.11.016

Annang TY, Yirenya-Tawiah D (2015) Report on baseline survey on organic waste management and composting in Ga-West Municipality. Utilization of Organic Waste to Improve Agricultural Productivity (UOWIAP) in Ga West Project. Institute for Environment and Sanitation Studies University of Ghana

Ansah B (2014) Characterization of municipal solid waste in three selected communities in the Tarkwa Township of Tarkwa Nsuaem Municipality in Ghana. Kwame Nkrumah University of Science and Technology, Kumasi

Benito M, Masaguer A, De Antonio R, Moliner A (2005) Use of pruning waste compost as a component in soilless growing media. Bioresour Technol 96:597-603. https://doi.org/10.1016/j.biort ech.2004.06.006

Bernal MP, Alburquerque JA, Moral R (2009) Composting of animal manures and chemical criteria for compost maturity assessment. A review. Bioresour Technol 100:5444-5453. https://doi. org/10.1016/j.biortech.2008.11.027

Bremner J (1965) Total nitrogen 1. In: Black CA (ed) Methods of soil analysis. Part 2. Chemical and microbiological properties. Number 9 in series Agronomy. American Society of Agronomy, Inc., Madison, pp 1149-1178

Brinton W (2004) Compost quality standards and guidelines. An international view. Final report to New York State Association of Recyclers. Woods End Research Laboratory, Mt Vernon

CCME (2005) Guidelines for compost quality. Winnipeg, Manitoba

Chatterjee N, Flury M, Hinman C, Cogger CG (2013) Chemical and physical characteristics of compost leachates. A Review Report prepared for the Washington State Department of Transportation Washington State University 
Chen Y-X, Huang X-D, Han Z-Y, Huang X, Hu B, Shi D-Z, Wu W-X (2010) Effects of bamboo charcoal and bamboo vinegar on nitrogen conservation and heavy metals immobility during pig manure composting. Chemosphere 78:1177-1181. https://doi. org/10.1016/j.chemosphere.2009.12.029

Cherif $\mathrm{H}$ et al (2009) Effects of municipal solid waste compost, farmyard manure and chemical fertilizers on wheat growth, soil composition and soil bacterial characteristics under Tunisian arid climate. Eur J Soil Biol 45:138-145. https://doi.org/10.1016/j. ejsobi.2008.11.003

Cointreau SJ (1982) Environmental management of urban solid wastes in developing countries: a project guide. International Bank for Reconstruction and Development Washington, DC (USA). Urban Development Dept, New York

Cooperband L (2002) The art and science of composting. Center for Integrated agricultural systems, University of WisconsinMadison, Madison

Delgado A, Garcia-Morales J, del Río RS, Sales D (2002) Stability and maturity indexes of compost. WIT Trans Ecol Environ 2002:56

Diacono M, Montemurro F (2015) Effectiveness of organic wastes as fertilizers and amendments in salt-affected soils. Agriculture 5:221-230. https://doi.org/10.3390/agriculture5020221

Douti NB, Abanyie SK, Ampofo S (2017) Solid waste management challenges in urban areas of Ghana: a case study of Bawku municipality. IJG 8:494-513. https://doi.org/10.4236/ ijg.2017.84026

El Fels L, Zamama M, El Asli A, Hafidi M (2014) Assessment of biotransformation of organic matter during co-composting of sewage sludge-lignocelullosic waste by chemical, FTIR analyses, and phytotoxicity tests. Int Biodeterior Biodegrad 87:128-137. https ://doi.org/10.1016/j.ibiod.2013.09.024

El-Fadel M, Findikakis AN, Leckie JO (1997) Environmental impacts of solid waste landfilling. J Environ Manag 50:1-25. https://doi. org/10.1006/jema.1995.0131

Eusufzai MK, Deb SK, Maeda T, Fujii K (2013) Mass loss and C and $\mathrm{N}$ release from decomposing fresh and composted residues as affected by cold climate conditions. Environ Nat Resour Res 3:116. https://doi.org/10.5539/enrr.v3n2p116

Gabbay O (2010) Assessment of the Avenor Pilot Community composting facility and its adaptability in other Accra Sub-Metro Areas. CHF International Ghana, Accra

Garcia C, Hernandez T, Costa F (1991) Changes in carbon fractions during composting and maturation of organic wastes. Environ Manag 15:433-439. https://doi.org/10.1007/bf02393889

García C, Hernández T, Costa F (1990) The influence of composting and maturation processes on the heavy-metal extractability from some organic wastes. Biol Waste 31:291-301. https://doi. org/10.1016/0269-7483(90)90086-8

Ghana Statistical Service (2012) Population and housing census: summary report of final results. Ghana Statistical Service, Accra

Ghana Statistical Service (2014) Population and housing census. District analytical report. GA West Municipality, Ghana

Gómez RB, Lima FV, Ferrer AS (2006) The use of respiration indices in the composting process: a review. Waste Manag Res 24:37-47. https://doi.org/10.1177/0734242x06062385

Gregorich EG, Carter MR (2007) Soil sampling and methods of analysis. CRC Press, Boca Raton

Guerrero LA, Maas G, Hogland W (2013) Solid waste management challenges for cities in developing countries. Waste Manag (Oxford) 33:220-232. https://doi.org/10.1016/j.wasma n.2012.09.008

Hanc A, Szakova J, Svehla P (2012) Effect of composting on the mobility of arsenic, chromium and nickel contained in kitchen and garden waste. Bioresour Technol 126:444-452. https://doi. org/10.1016/j.biortech.2011.11.053
Henry RK, Yongsheng Z, Jun D (2006) Municipal solid waste management challenges in developing countries-Kenyan case study. Waste Manag (Oxford) 26:92-100. https://doi.org/10.1016/j. wasman.2005.03.007

Himanen M, Hänninen K (2011) Composting of bio-waste, aerobic and anaerobic sludges - effect of feedstock on the process and quality of compost. Bioresour Technol 102:2842-2852. https:// doi.org/10.1016/j.biortech.2010.10.059

Huang GF, Wong JWC, Wu QT, Nagar BB (2004) Effect of C/N on composting of pig manure with sawdust. Waste Manag (Oxford) 24:805-813. https://doi.org/10.1016/j.wasman.2004.03.011

Inbar Y, Hadar Y, Chen Y (1993) Recycling of cattle manure: the composting process and characterization of maturity. J Environ Qual 22:857-863. https://doi.org/10.2134/jeq1993.0047242500 2200040032x

Jakubus M, Czekała J (2010) Chromium and nickel speciation during composting process of different biosolids. In: Paper presented at the Fresenius Environmental Bulletin, Freising, Germany

Kathirvale S, Muhd Yunus MN, Sopian K, Samsuddin AH (2004) Energy potential from municipal solid waste in Malaysia. Renew Energ 29:559-567. https://doi.org/10.1016/j.renen e.2003.09.003

Khater E (2015) Some physical and chemical properties of compost. Int J Waste Resour 5:1-5. https://doi.org/10.4172/2252-5211.10001 72

Larney FJ, Olson AF, DeMaere PR, Handerek BP, Tovell BC (2008) Nutrient and trace element changes during manure composting at four southern Alberta feedlots. Can J Soil Sci 88:45-59. https:// doi.org/10.4141/CJSS07044

Liu J, Lu Z, Yang J, Xing M, Yu F, Guo M (2012) Effect of earthworms on the performance and microbial communities of excess sludge treatment process in vermifilter. Bioresour Technol 117:214-221. https://doi.org/10.1016/j.biortech.2012.04.096

Ma Y, Dickinson NM, Wong MH (2003) Interactions between earthworms, trees, soil nutrition and metal mobility in amended $\mathrm{Pb} /$ $\mathrm{Zn}$ mine tailings from Guangdong, China. Soil Biol Biochem 35:1369-1379. https://doi.org/10.1016/S0038-0717(03)00216-5

Miaomiao H, Wenhong L, Xinqiang L, Donglei W, Guangming T (2009) Effect of composting process on phytotoxicity and speciation of copper, zinc and lead in sewage sludge and swine manure. Waste Manag (Oxford) 29:590-597. https://doi.org/10.1016/j. wasman.2008.07.005

Miezah K, Obiri-Danso K, Kádár Z, Fei-Baffoe B, Mensah MY (2015) Municipal solid waste characterization and quantification as a measure towards effective waste management in Ghana. Waste Manag (Oxford) 46:15-27. https://doi.org/10.1016/j.wasma n.2015.09.009

Mitelut AC, Popa ME (2011) Seed germination bioassay for toxicity evaluation of different composting biodegradable materials. Rom Biotechnol Lett 16:121-129

Moldes A, Cendón Y, Barral MT (2007) Evaluation of municipal solid waste compost as a plant growing media component, by applying mixture design. Bioresour Technol 98:3069-3075. https://doi. org/10.1016/j.biortech.2006.10.021

Nakhshiniev B, Biddinika MK, Gonzales HB, Sumida H, Yoshikawa K (2014) Evaluation of hydrothermal treatment in enhancing rice straw compost stability and maturity. Bioresour Technol 151:306313. https://doi.org/10.1016/j.biortech.2013.10.083

Nartey EG (2013) Faecal sludge reuse in urban and peri-urban crop production. University of Ghana, Ghana

Niazi NK et al (2016) Chapter 7-removal and recovery of metals by biosorbents and biochars derived from biowastes. Environmental materials and waste. Academic Press, London, pp 149-177. https ://doi.org/10.1016/B978-0-12-803837-6.00007-X

Noguera P, Abad M, Puchades R, Maquieira A, Noguera V (2003) Influence of particle size on physical and chemical properties of 
coconut coir dust as container medium. Commun Soil Sci Plant Anal 34:593-605. https://doi.org/10.1081/CSS-120017842

Ofori RA (2013) Integrated waste management-source separation and composting of household waste in the Ayuom Farming Community in the Bosomtwe District of the Ashanti Region. Kwame Nkrumah University of Science and Technology, Kumasi

Ofosu-Budu GK, Hogarh JN, Fobil JN, Quaye A, Danso SKA, Carboo D (2010) Harmonizing procedures for the evaluation of compost maturity in two compost types in Ghana. Resour Conserv Recycl 54:205-209. https://doi.org/10.1016/j.resconrec.2009.08.001

Osei FB, Duker AA (2008) Spatial dependency of $V$. cholera prevalence on open space refuse dumps in Kumasi, Ghana: a spatial statistical modelling. Int J Health Geogr 7:62

Oteng-Ababio M, Melara Arguello JE, Gabbay O (2013) Solid waste management in African cities: sorting the facts from the fads in Accra, Ghana. Habitat Int 39:96-104. https://doi.org/10.1016/j. habitatint.2012.10.010

Page A, Miller R, Keeney D (1982) Methods of soil analysis. Part 2. Chemical and microbiological properties. American Society of Agronomy. In: Soil Science Society of America

Pampuro N, Bisaglia C, Romano E, Brambilla M, Foppa Pedretti E, Cavallo E (2017) Phytotoxicity and chemical characterization of compost derived from pig slurry solid fraction for organic pellet production. Agric 7:94. https://doi.org/10.3390/agriculture7110 094

Pascual JA, Ayuso M, Garcia C, Hernández T (1997) Characterization of urban wastes according to fertility and phytotoxicity parameters. Waste Manag Res 15:103-112. https://doi.org/10.1177/07342 42X9701500108

Peter S (2002) Are the municipal solid waste management practices causing flooding during the rainy season in Accra, Ghana. Afr J Environ Assess Manag 4:56-62

Qian X, Shen G, Wang Z, Guo C, Liu Y, Lei Z, Zhang Z (2014) Cocomposting of livestock manure with rice straw: characterization and establishment of maturity evaluation system. Waste Manag (Oxford) 34:530-535. https://doi.org/10.1016/j.wasma n.2013.10.007

Rashad FM, Saleh WD, Moselhy MA (2010) Bioconversion of rice straw and certain agro-industrial wastes to amendments for organic farming systems: 1 . Composting, quality, stability and maturity indices. Bioresour Technol 101:5952-5960. https://doi. org/10.1016/j.biortech.2010.02.103

Roca-Pérez L, Martínez C, Marcilla P, Boluda R (2009) Composting rice straw with sewage sludge and compost effects on the soilplant system. Chemosphere 75:781-787. https://doi.org/10.1016/j. chemosphere.2008.12.058

Roe NE, Stoffella PJ, Graetz D (1997) Composts from various municipal solid waste feedstocks affect vegetable crops. II. Growth, yields, and fruit quality. J Am Soc Hortic Sci 122:433-437

Romero C, Ramos P, Costa C, Márquez MC (2013) Raw and digested municipal waste compost leachate as potential fertilizer: comparison with a commercial fertilizer. J Clean Prod 59:73-78. https:// doi.org/10.1016/j.jclepro.2013.06.044

Rynk R (1992) On-farm composting handbook. Northeast Regional Agricultural Engineering Service, Ithaca

Said-Pullicino D, Erriquens FG, Gigliotti G (2007) Changes in the chemical characteristics of water-extractable organic matter during composting and their influence on compost stability and maturity. Bioresour Technol 98:1822-1831. https://doi.org/10.1016/j. biortech.2006.06.018

Saka D, Akiti TT, Osae S, Appenteng MK, Gibrilla A (2013) Hydrogeochemistry and isotope studies of groundwater in the Ga West
Municipal Area, Ghana. Appl Water Sci 3:577-588. https://doi. org/10.1007/s13201-013-0104-3

Sangodoyin A, Amori A (2013) Aerobic composting of cassava peels using cow dung, sewage sludge and poultry manure as supplements. EIJST 2:22-34

Selim SM, Zayed MS, Atta HM (2012) Evaluation of phytotoxicity of compost during composting process. Nat Sci 10:69-77

Singh RP, Ibrahim MH, Esa N, Iliyana MS (2010) Composting of waste from palm oil mill: a sustainable waste management practice. Rev Environ Sci Biol 9:331-344. https://doi.org/10.1007/ s11157-010-9199-2

Sommer SG (2001) Effect of composting on nutrient loss and nitrogen availability of cattle deep litter. Eur J Agron 14:123-133. https:// doi.org/10.1016/S1161-0301(00)00087-3

Taiwo AM (2011) Composting as a sustainable waste management technique in developing countries. J Environ Sci Technol 4:93-102

Tchobanoglous G, Kreith F (2002) Handbook of solid waste management. McGraw-Hill, New York

Thomas-Hope E (1998) Solid waste management: critical issues for developing countries. Canoe Press, Kingston

Tiquia SM, Tam NFY (1998) Elimination of phytotoxicity during cocomposting of spent pig-manure sawdust litter and pig sludge. Bioresour Technol 65:43-49. https://doi.org/10.1016/S0960 -8524(98)00024-8

Tiquia SM, Tam NF, Hodgkiss IJ (1996) Effects of composting on phytotoxicity of spent pig-manure sawdust litter. Environ Pollut 93:249-256. https://doi.org/10.1016/S0269-7491(96)00052-8

Walkley A, Black IA (1934) An examination of the degtjareff method for determining soil organic matter, and a proposed modification of the chromic acid titration method. Soil Sci 37:29-38

Warman PR (1999) Evaluation of seed germination and growth tests for assessing compost maturity. Compost Sci Util 7:33-37. https ://doi.org/10.1080/1065657X.1999.10701972

Watanabe FS, Olsen SR (1965) Test of an ascorbic acid method for determining phosphorus in water and $\mathrm{NaHCO}_{3}$ extracts from soil1. Soil Sci Soc Am J 29:677-678. https://doi.org/10.2136/ sssaj1965.03615995002900060025x

Wong JWC, Li K, Fang M, Su DC (2001) Toxicity evaluation of sewage sludges in Hong Kong. Environ Int 27:373-380. https://doi. org/10.1016/S0160-4120(01)00088-5

Yoada RM, Chirawurah D, Adongo PB (2014) Domestic waste disposal practice and perceptions of private sector waste management in urban Accra. BMC Public Health 14:697. https://doi. org/10.1186/1471-2458-14-697

Zheljazkov VD, Warman PR (2004) Phytoavailability and fractionation of copper, manganese, and zinc in soil following application of two composts to four crops. Environ Pollut 131:187-195. https:// doi.org/10.1016/j.envpol.2004.02.007

Zheng G-D, Gao D, Chen T-B, Luo W (2007) Stabilization of nickel and chromium in sewage sludge during aerobic composting. $\mathrm{J}$ Hazard Mater 142:216-221. https://doi.org/10.1016/j.jhazm at.2006.08.003

Zucconi F (1981) Evaluating toxicity of immature compost. Biocycle 22:54-57

Publisher's Note Springer Nature remains neutral with regard to jurisdictional claims in published maps and institutional affiliations. 